Електронне наукове фахове видання з економічних наук «Modern Economics», №18 (2019), 6-14 https://modecon.mnau.edu.ua | ISSN 2521-6392

JEL Classification: J08, 040, E22, J22 DOI: https://doi.org/10.31521/modecon.V18(2019)-01

Amanda Afifah Putri, Postgraduate Student, Faculty of Economy, Sriwijaya University, Palembang, Indonesia

ORCID ID: 0000-0002-5142-5370

e-mail: afifahputriamanda18@gmail.com

Kadir Syamsurijal Abdul, PhD (Economics), Lecturer at Faculty of Economy, Sriwijaya University, Palembang, Indonesia

e-mail: syamsurijalkadir@gmail.com

Chodijah Rosmiayati, Lecturer at Faculty of Economy, Sriwijaya University, Palembang, Indonesia

e-mail: roossaleh@gmail.com

\title{
Factors Affecting Labor Absorption: Case Study In South Sumatra Province
}

Abstract. The study was conducted to analyze the influence of the provincial minimum wage, economic growth, investment, agricultural sector minimum wage and non-agricultural sector minimum wage on labor absorption in South Sumatra in 1998-2017. The data used in this study is secondary data sourced from the Statistical Center of South Sumatra and publications from previous studies that were related to this study. Data were analyzed by multiple regression analysis and collected from 19982017 (20-year period) The results of the study are expected to be a reference for further research and considered in implementing policies of labor issues in South Sumatra.

Purpose. The purpose of this study is to determine the factors that influence labor absorption in South Sumatra in 1998-2017.

Result. The results of this study indicate that the provincial minimum wage has no effect on labor absorption in South Sumatra. However, economic growth, investment, and minimum wages in the agricultural and non-agricultural sectors affect labor absorption in South Sumatra.

Conclusion. The results of the study showed that the government in South Sumatra should be concerned in preparing wage policies both for the provincial minimum wage and the sectoral minimum wage by considering various related parties such as companies and workers themselves. Also, economic growth and the investment value which distributed evenly can increase labor absorption and create prosperity for workers.

Keywords: Provincial Minimum Wages; Economic Growth; Investment; Agricultural Sector Minimum Wages; NonAgricultural Sector Minimum Wages; Labor Absorption.

\section{удк 332.1}

Аманда А. П., аспірант, факультет економіки, Університет Шривіджая, Палембанг, Індонезія

Кадір С. А., кандидат економічних наук, викладач факультету економіки, Університет Шривіджая, Палембанг, Індонезія

Чодіджах Р., кандидат економічних наук, викладач факультету економіки, Університет Шривіджая, Палембанг, Індонезія

\author{
Фактори, що впливають на працемісткість: \\ тематичне дослідження в провінції Південна Суматра
}

Анотація. Дослідження було проведено з метою аналізу впливу мінімальної заробітної плати в провінціях, економічного зростання, інвестицій, мінімальної заробітної плати аграрного сектору та мінімальної заробітної плати несільськогосподарського сектору на працемісткість у Південній Суматрі в 1998-2017 роках. Дані, що використовуються в цьому дослідженні, є вторинними даними, отриманими зі статистичного центру Південної Суматри та з відповідних публікацій попередніх досліджень. Дані були проаналізовано за допомогою множинного регресійного аналізу та зібрані за 20-річний період. Очікується, що результати дослідження стануть довідковим матеріалом для подальших досліджень та будуть враховані при впровадженні політики трудових відносин у Південній Суматрі. 2017 роках.

Метою дослідження є визначення факторів, що впливають на працемісткість у Південній Суматрі в 1998-

Результати дослідження свідчать, що мінімальна заробітна плата на рівні провінцій не впливає на працемісткість у Південній Суматрі. Економічне зростання, інвестиції та мінімальна заробітна плата в аграрному секторі та несільськогосподарському секторі впливають на працемісткість у Південній Суматрі.

Отже, на основі отриманих результатів можна зробити висновок, що уряд Південної Суматри має бути зацікавлений у розробці політики заробітної плати як щодо мінімальної заробітної плати в провінціях, так $i$

Стаття надійшла до редакції: 13.11 .2019

Received: 13 November 2019 
мінімальної заробітної плати в секторах, враховуючи пов'язані сторони (i компанії, і працівників). Крім того, економічне зростання та рівномірно розподілена інвестиційна вартість можуть підвищити працемісткість та сприяти добробуту працівників.

Ключові слова: провінційна мінімальна заробітна плата; економічне зростання; інвестиції; мінімальна заробітна плата аграрного сектору; мінімальна заробітна плата несільськогосподарського сектору; працемісткість.

Statement of problem. Labor Absorption is fundamental to human life and consists of economic and social aspects because labor is one of the supporting factors of economic development in a country that aims to achieve equitable economic development. Employment is still a problem that cannot be solved. It happens because the population increases faster than the number of jobs. According to classics by authors such as Adam Smith, David Ricardo and Thomas Robert Malthus, there is always a competition between the available jobs and the increasing population, regardless of the fact that the human population will eventually exceed the available jobs (output). People tend to have difficulties in getting jobs. Getting jobs may be able to increase people's welfare, but unemployment will push them to lower the standard of living in their country (Irawan and Suparmoko, 2002).
The development of the structure of labor forces in South Sumatra from 2010 to 2017 demonstrated better transformation of the number of working-age population in South Sumatra which fluctuatively increased. From Table 1, it can be seen that there was an increase in employment opportunities from 2010 to 2017. The high demand for labor means that there were opportunities for unemployed people.

By examining the relationship between the production of goods and the demand for labor, it was found that the determining factor is wages. In general, wages have a strategic position, both for workers and their families, for companies and for national interests. For workers, wages are needed to support themselves and their families and to increase their productivity. For companies, wages are one component of production costs which can reduce their profits.

Table 1 Labor Conditions in South Sumatera

\begin{tabular}{|l|c|c|c|c|}
\hline Year & Population (15+) & Workforce & Employed & Unemployed \\
\hline 2010 & 5218600 & 3665044 & 3421193 & 243851 \\
2011 & 5299957 & 3770673 & 3553104 & 217569 \\
2012 & 5385732 & 3746373 & 3532932 & 213441 \\
2013 & 5848251 & 3646996 & 3464620 & 182376 \\
2014 & 5643636 & 3885674 & 3692806 & 192868 \\
2015 & 5741308 & 3934787 & 3695866 & 238921 \\
2016 & 5837451 & 4178794 & 3998637 & 180157 \\
2017 & 5933755 & 4123669 & 3942534 & 181135 \\
\hline
\end{tabular}

Source: Statistical Center of South Sumatra (BPS, 2017)

Based on fig. 1, the minimum wage in South Sumatra Province has increased by 8.2 percent, at Rp182,000, - on the average, compared to the previous year. Increasing minimum wages tends to make employers reduce the amount of labor in the production process.

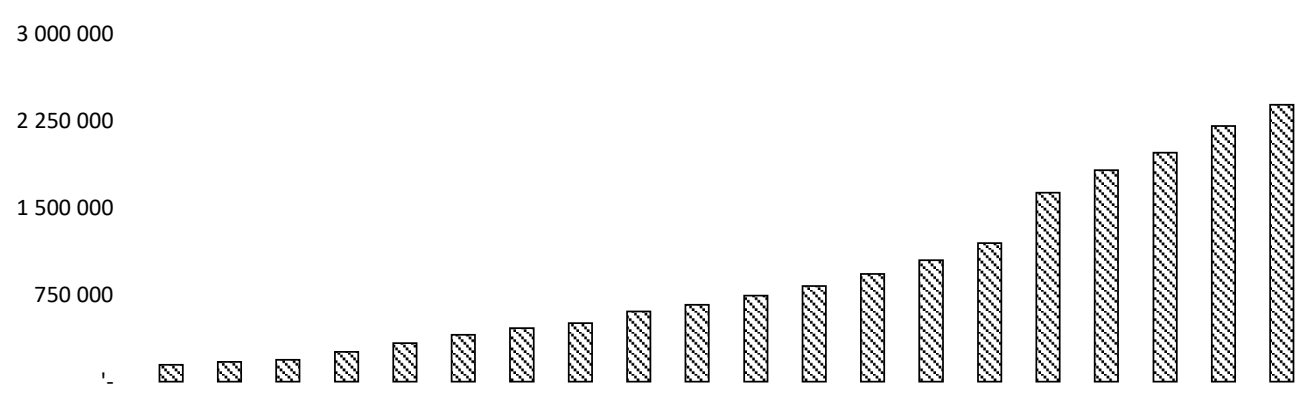

19981999200020012002200320042005200620072008200920102011201220132014201520162017

ه South Sumatra Minimum Wage

Figure 1 - Minimum Wage from 2010-2017 in South Sumatra (in Rupiah)

Source: Statistical Center of South Sumatra (BPS, 2017)

The unemployment rate is caused by fluctuating economic growth since the rate of economic growth goes hand in hand with the absorption rate of the labor force, especially in South Sumatra. The economic growth from 
2013 to 2014 decreased by $0.52 \%$, from $5.31 \%$ to $4.79 \%$. But in the following year (2014 to 2015), the rate of economic growth in South Sumatra increased by $1,09 \%$, from $4,42 \%$ to $5,51 \%$. The development rate of economic growth in the province of South Sumatra today has a major influence on the number of workers and can reduce the number of unemployed.

The improvement of this economic growth was not followed by an increasingly conducive economic situation, coupled with overlapping central and regional policies, which eventually will affect investors' interest in investing their capital and will thus delay the creation of new jobs. The level of investment in South Sumatra has increased with a focus on several sectors such as agricultural and non-agricultural sectors, which increase labor productivity with a fairly minimal increase in employment. The realization of investment will create jobs in each sector. In South Sumatra Province, labor absorption in the agricultural sector decreased from $54.74 \%$ in 2015 to $48.25 \%$ in 2017, while labor absorption in the nonagricultural sector experienced an increase from $45.31 \%$ in 2013 to $51.75 \%$ in 2017. Data showed that labor absorption in the agricultural sector is lower than in the non-agricultural sector. The development of the provincial sectoral minimum wage in South Sumatra, both in the agricultural and non-agricultural sectors, continues to increase from year to year, in opposite to the labor absorption rate. Based on the description, this study aims to analyze the effect of the provincial minimum wage, economic growth, investment, and agricultural and nonagricultural sector minimum wage on employment in South Sumatra Province.

Literature Review. Labor absorption is related to the amount of workforce which is required by the company/institution. According to the study from Gindling dan Terrell (2006), the wage rate has an effect on labor absorption. Wage is determined by involving the evaluation from employees' contributions, as a form of direct and indirect appreciation, based on the capability of the organization and law (Fopuhunda, et al, 2011). Danziger (2009) mentioned that the decreasing minimum wage rate has good effects on the country in a long term, of which the unemployment may be decreased due to absorbed labor in the labor market.

Magruder (2013) mentioned that minimum wage rate has a negative relation with the labor demand, of which the increasing minimum wage rate will reduce the amount of labor demand and decrease the labor absorption as well.

Labor absorption may be affected by an increase in gross regional domestic product (GRDP). It was supported by the study from Junaidi (2013) that GRDP has influenced working opportunities in North Sulawesi province. GRDP is a reflection of economic growth (increased output). If GRDP increased, the amount of working opportunities would be increased too.

According to a study about labor absorption and public welfare from Miar (2014), the change in the output of economic activities showed that economic growth will always be followed by the amount of labor absorption, and an increase of the economic growth would increase public welfare. Agrawal (1996) considered that labor forces in Indonesia are the beneficiary of achieved economic growth. Industries have been growing rapidly and creating more working opportunities with relatively higher wages.

Islam (2004) stated the importance of identifying the elements of economic growth which side with poor people and alleviate poverty by increasing labor absorption and the productivity rate. The relationship between poverty alleviation, labor elasticity, and economic growth has shown its impacts from labor forces and labor market towards the alleviation of poverty. A study from Boltho dan Glyn (1995) found that there was a variation of labor elasticity, which showed the interaction between economic growth and labor absorption was affected by macroeconomic policy and the national economic situation. The fluctuation of labor absorption can be explained, for example, by a company that would decrease the number of their employees as the company deteriorated, and would increase them as the company improved.

Sulistiawati (2012) concluded that wages have influenced labor absorption. Labor forces in primary sectors generally have lower education as well as lower productivity. Therefore, an increase of minimum wage will reduce the labor forces in this sector. Based on the study from SMERU (2001) about the impact of minimum wage policy on minimum wage rate and labor absorption in urban cities in Indonesia, an increase of minimum wage rate would replace half of blue-collar labor with white collar workers (educated/professional workers). A study from Kapos (2005) has utilized labor elasticity as a tool to detect larger employment opportunities, productivity growth, and structural economic growth. By investigating historical trends on the intensity of employment and population growth, a clearer picture of various employments can be described.

Conceptual Framework. Based on the literature review and previous studies, the framework of this study is shown in the following figure: 


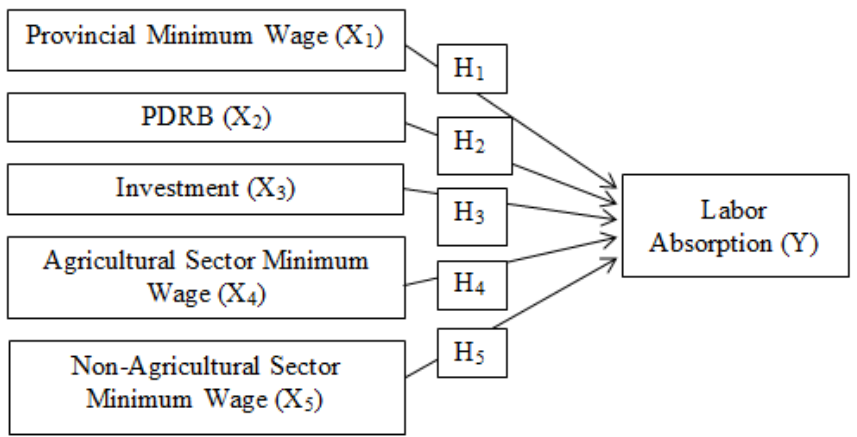

Figure 2 - Conceptual Framework

Source: author's calculations

Figure 2 is a research plan to be followed in analyzing the factors that influence labor absorption in South Sumatra in 1998-2017. Based on the literature review, the hypotheses constructed from this research are:

1. Hypothesis 1: Provincial Minimum Wage has a negative and significant effect on Labor Absorption in South Sumatra Province

2. Hypothesis 2: Economic Growth has a positive and significant effect on Labor Absorption in South Sumatra Province

3. Hypothesis 3: Investment has a positive and significant effect on Labor Absorption in South Sumatra Province

4. Hypothesis 4: The Agricultural Sector Minimum Wage has a negative and significant effect on Labor Absorption in South Sumatra Province

5. Hypothesis 5: Non-Agricultural Sector Minimum Wages has a negative and significant effect on Labor Absorption in South Sumatra Province.

Model and Method Analysis. Data used in this study are secondary data sourced from the Central Statistics Agency of South Sumatra Province and relevant previous studies, from 1998 to 2017. The analysis technique used in this research is descriptive analysis techniques and quantitative methods using multiple linear regression, testing classic assumptions, and hypothesis testing. The following is the analysis of the model used:

\section{$P T K=\beta_{0}+\beta_{1} U M P+\beta_{2} P E+\beta_{3} I N V+\beta_{4} U M P T+\beta_{5} U M N P T+\varepsilon$}

Where: $\beta_{1}-\beta_{5}$ : regression coefficient;

$\beta_{0}$ : constants;

PTK: labor absorption;

$U M P$ : provincial minimum wage;

$P E$ : economic growth;

INV: investment;

UMPT: agricultural sector minimum wage;

UMNPT : non-agriculture sector minimum wage; $\varepsilon$ : error term.

Provincial Minimum Wage (UMP) is the provincial minimum wage that applies in South Sumatra Province and is measured in Rupiah. Economic growth which is proxied by the Gross Domestic Product (GRDP) of South Sumatra Province according to the constant prices in 2010 as a measure to assess economic growth. The unit used is million Rupiah (IDR - Indonesian Rupiah). Investment is the value of real investment received in South Sumatra Province in 1998 - 2017. In the form of billions of Rupiah. The agricultural sector minimum wage is the sectoral minimum wage based on the main employment in the applicable agricultural sector, and the non-agricultural sector minimum wage is the average sectoral minimum wage rate based on the main employment in the applicable non-agricultural sector measured in Rupiah.

Results. The population in South Sumatra Province has increased and this also occurs in the population of working age. If the additional workers are not absorbed by the existing economic sectors, it will increase the rate of unemployment.

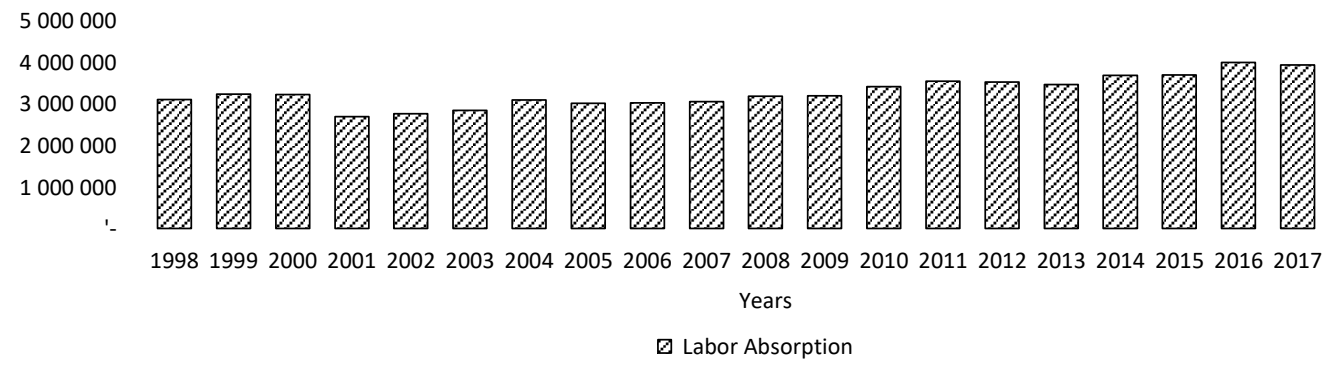

Figure 3 - Labor Absorption in South Sumatra

Source: Statistical Center of South Sumatra (BPS, 2017) 
Figure 3 illustrates the rate of employment in the labor absorption in South Sumatra occurred in 2016 at province of South Sumatra in 1998-2017. The highest approximately 3,998,637 people.

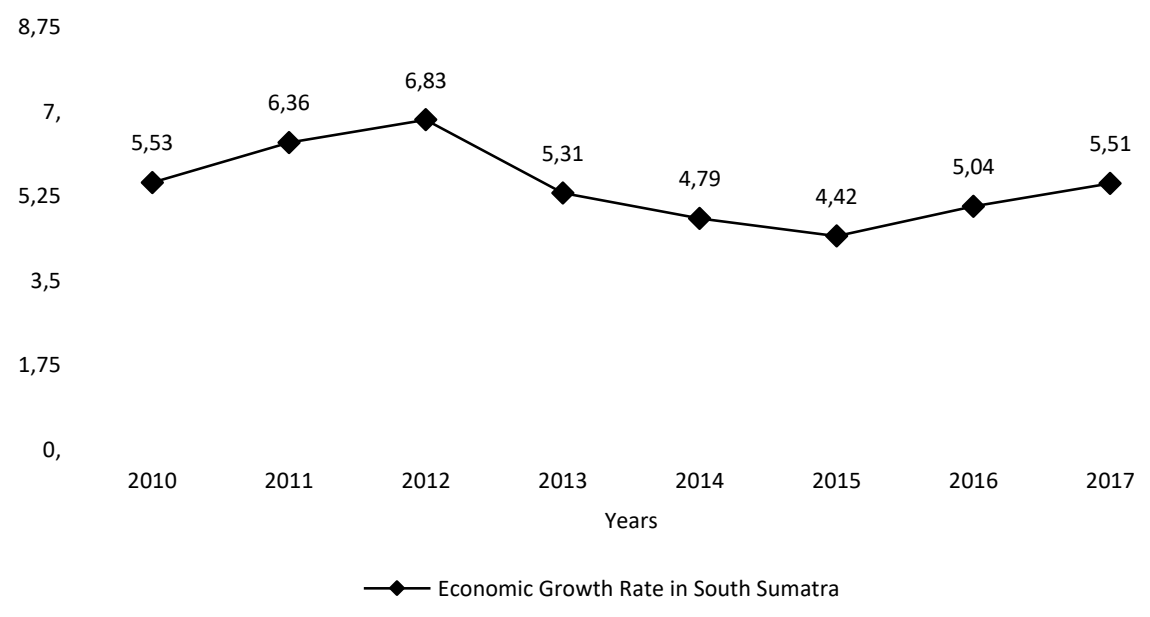

Figure 4 - Economic Growth Rate in South Sumatra

Source: Statistical Center of South Sumatra (BPS, 2017)

Figure 4 illustrates that the improvement of economic influence on the number of workers and can reduce growth in the province of South Sumatra has a big unemployment.

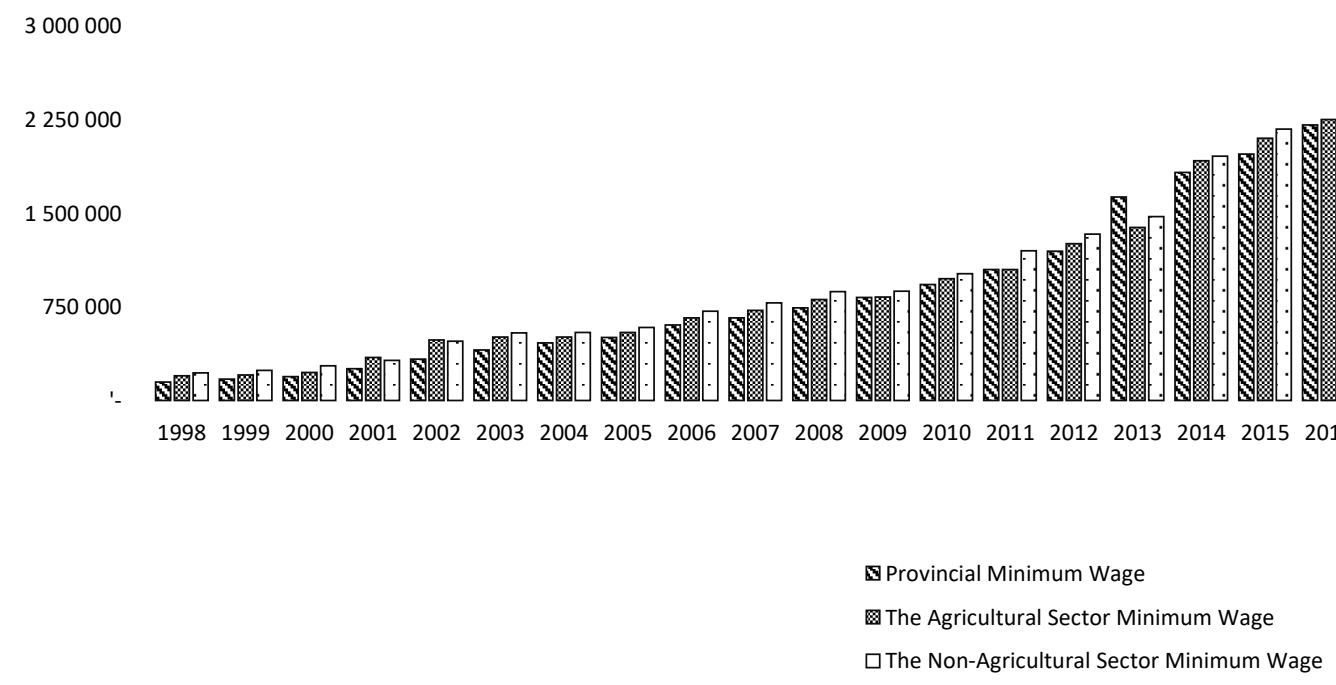

Figure 5 - Provincial Minimum Wage and Sectoral Minimum Wage in South Sumatra

Source: Statistical Center of South Sumatra (BPS, 2017)

Figure 5 illustrates annual data on provincial minimum wages, agricultural and non-agricultural minimum wages in South Sumatra, which tend to increase every year.
Econometric Analysis. The normality test aims to test whether the standardized residual values in the regression model are normally distributed or not. This normality assumption test is carried out using the Jarque-Bera test. 


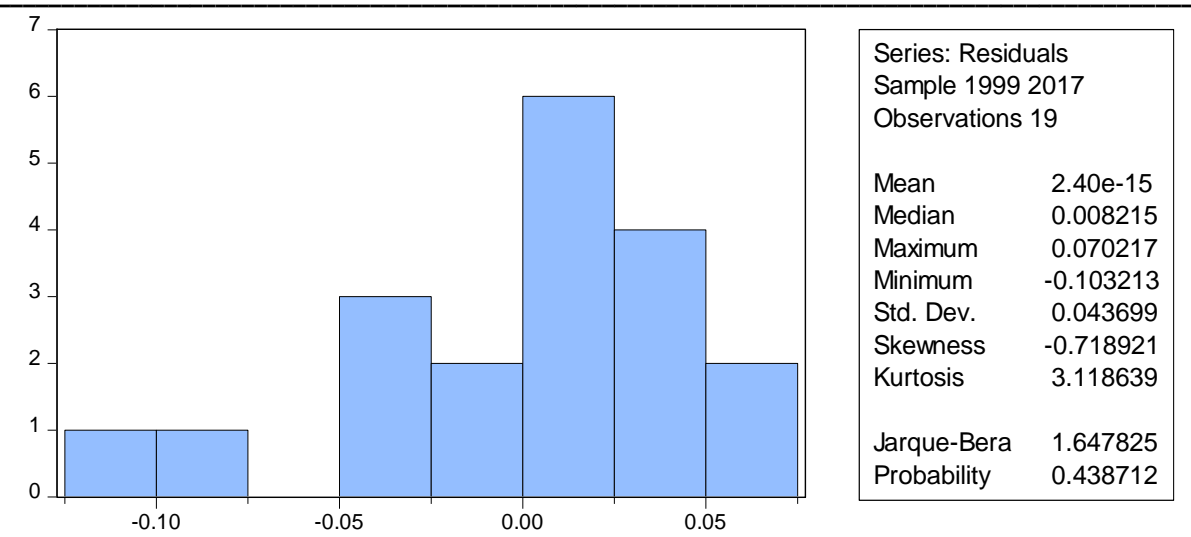

Figure 6 - Normality Test

Source: Outcome data

Figure 6 illustrates normality test, The normality test results show that the value of Prob. JB count is $0.438712>$ 0.05 . It can be concluded that the residuals are normally distributed which means the classical assumptions about normality have been fulfilled.

Table 2 Multicollinearity Test

\begin{tabular}{|c|c|c|c|c|c|}
\hline Model & UMP & PE & INV & UMPT & UMNPT \\
\hline UMP & 1.000000 & 0.141245 & 0.198254 & -0.553699 & -0.526178 \\
PE & 0.141245 & 1.000000 & -0.510599 & 0.131477 & 0.109380 \\
INV & 0.198254 & -0.510599 & 1.000000 & -0.339082 & 0.082019 \\
UMPT & -0.553699 & 0.131477 & -0.339082 & 1.000000 & 0.100196 \\
UMNPT & -0.526178 & 0.109380 & 0.082019 & 0.100196 & 1.000000 \\
\hline
\end{tabular}

Source: Outcome data

Table 2 shows a multicollinearity test is performed to determine whether the regression model correlates with independent variables. The results of the multicollinearity test above indicate that for the variables provincial minimum wage, economic growth, and investment, the minimum wage in the agricultural and non-agricultural sector minimum wage have a value less than 0.80 . Hence, it shows that the five variables do not experience multicollinearity.

Table 3 Heteroscedasticity Test

\begin{tabular}{|l|c|l|l|}
\hline \multicolumn{4}{|c|}{ Heteroskedasticity Test: Breusch-Pagan-Godfrey } \\
\hline F-statistic & 0.952391 & Prob. F(5,12) & 0.4806 \\
Obs*R-squared & 5.093873 & Prob. Chi-Square(5) & 0.4045 \\
Scaled explained SS & 2.526123 & Prob. Chi-Square(5) & 0.7726 \\
\hline
\end{tabular}

Source: Outcome data

The heteroscedasticity test is used to determine if the variance is not constant and there is a strong relationship between residuals. Table 3 illustrates the heteroscedasticity test. The heteroscedasticity test results above indicate that the value of prob.obs $* r$-squared has a value $>$ alpha 0.05 which is equal to 0.4045 . It can be concluded that the regression model in this study did not experience heteroscedasticity problems.

Table 4 Autocorrelation Test (LM Test)

\begin{tabular}{|l|l|l|l|}
\hline \multicolumn{4}{|c|}{ Breusch-Godfrey Serial Correlation LM Test: } \\
\hline F-statistic & 1.510645 & Prob. F(2,11) & 0.2632 \\
Obs*R-squared & 4.094096 & Prob. Chi-Square(2) & 0.1291 \\
\hline
\end{tabular}

Source: Outcome data 
The autocorrelation test is used to determine whether there is a correlation between the error of the intruder in period $t$ and the error of the intruder in period $t-1$. The method used in this study is the LM (Langrange Multiplier) test method. Table 4 shows LM test, the results indicate that the value of prob.obs * $r$-squared is $0.1291>0.05$, so it can be concluded that the data in this study has no autocorrelation problems.

Table 5 Model Summary Multiple Regression Output Results

\begin{tabular}{|c|c|c|c|c|}
\hline Variable & Coefficient & Std. Error & t-Statictic & Prob. \\
\hline C & 16.94875 & 0.190952 & 88.75944 & 0.0000 \\
UMP & -0.188995 & 0.316247 & -0.597619 & 0.5604 \\
PE & 0.209692 & 0.038104 & 5.503088 & 0.0001 \\
INV & 0.020272 & 0.007523 & 2.694681 & 0.0184 \\
UMPT & -0.208104 & 0.090615 & -2.296583 & 0.0389 \\
UMNPT & -0.259963 & 0.027792 & -9.353836 & 0.0000 \\
\hline R-squared & 0.850599 & \multicolumn{3}{|c}{} \\
F-statistic & 14.80283 & Dean dependent var & 15.00251 \\
Prob(F-statistic) & 0.000057 & \multicolumn{4}{|c}{} \\
\hline
\end{tabular}

Source: author's computation

Based on the estimated model of the minimum wage variable, economic growth, investment, and agricultural and non-agricultural sector minimum wages, the estimation results are obtained using the multiple regression equation model. Then based on the results of the regression that has been done, the simultaneous equation model for the equation can be formulated as follows :

\section{$P T K=b_{0}+b_{1} U M P+b_{2} P E+b_{3} I N V+b_{4} U M P T+b_{5} U M N P T+\varepsilon$}

PTK=16.94875

\section{$0.188995 U M P+0.209692 P E+0.020272 I N V-$} $0.208104 U M P T-0.259963 U M N P T$

From the calculation results obtained that the Prob (Fstatistic) value of 0.000057 . Thus it can be concluded that the independent variables jointly affect the dependent variable. Processing results found that the value of R2 is 0.79 or $79 \%$, which means that the contribution of the variable minimum wage, economic growth, investment, and minimum wage in the agricultural and nonagricultural minimum wage in labor absorption is $79 \%$, while the remaining $21 \%$ is caused by other factors.

The Relationship of The Provincial Minimum Wage to Labor Absorption. The provincial minimum wage variable coefficient of -0.188995 shows a negative and insignificant sign with a probability value of 0.5604 . The absence of the influence of the provincial minimum wage on employment in this study is due to the fact that there are still many companies that provide wages to employees below the provincial minimum wage standard so that the impact on the declining work productivity of the labor force results in decreasing output growth and ultimately employment opportunities will not be created.

The Relationship of Economic Growth To Labor Absorption. The coefficient of economic growth variable is 0.209692 which shows a positive relationship with the variable of employment. If economic growth rises by 1 percent, then employment will increase by 0.209692 percent. Assuming other factors outside the model are considered constant. $T$ test results show that economic growth has a significant effect on employment with a probability value of 0.0001 . The results of this study are consistent with research conducted by Miar (2014) and Pardi (2007) who mentioned that changes in outputs of economic activity indicate that economic growth is always followed by a large amount of employment. Increased economic growth as seen from the value of GRDP in South Sumatra indicates that the amount of value added output or sales in all economic units in South Sumatra also increased, where the greater output or more sales made by the company will encourage companies to increase their labor demand so that production output can be increased. Hence, labor absorption will be increased as well.

The Relationship of Investment to Labor Absorption. The coefficient of the investment variable is 0.020272 which shows a positive relationship with the variable employment. If investment rises by 1 percent, then employment will increase by 0.020272 percent. T test results indicate that economic growth has a significant effect on employment with a probability value of 0.0184 . According to the theory by Harrod Domar, the increase in the level of output and employment can be done with the accumulation of capital (investment) and savings. Investment not only creates demand but also enlarges production capacity. This research is supported by the results of research conducted by Javed et al (2001), which shows that a positive relationship between investment and employment due to investment refers to spending on business expansion and new equipment that is managed and driven by human labor, so that increased investment can increase employment.

The Relationship Between The Agricultural Sector Minimum Wage to Labor Absorption. The coefficient of the variable minimum wage in the agricultural sector is 0.208104 , which shows a negative relationship with the variable employment. If the minimum wage in the 
agriculture sector rises by 1 percent, then employment will experience a decrease of 0.208104 percent. T test results show that economic growth has a significant effect on employment with a probability value of 0.0389 . The results of the analysis can be seen that the negative relationship between the minimum wage in the agricultural sector and employment shows compatibility with the theory. According to Simanjuntak (1985) wages are considered as a burden by employers, since the greater the wage level the smaller the proportion of profits to be gained by employers.

The Relationship of Non-Agricultural Sector Minimum Wages to Labor Absorption. The coefficient of the variable minimum wage in the non-agricultural sector is -0.259963 , which shows a negative relationship with the variable employment. If the minimum wage in the agricultural sector rises by 1 percent, then employment will experience a decrease of 0.259963 percent. $T$ test results show that economic growth has a significant effect on employment with a probability value of 0.0000 . The results of this study are supported by a study conducted by Magruder (2013), who concluded that minimum wages have a negative relationship with labor demand, where the rise of minimum wage in non-agricultural sector can result in decreasing amount of labor demand in South
Sumatera. This is because if wages rise while the prices of other inputs are fixed, then the price of labor is relatively more expensive than other inputs, thus encouraging employers to replace workers with relatively higher wages with other workers who accept lower wages, or reduce the number of total workers.

Conclusions. The results showed that the provincial minimum wage did not significantly influence employment in South Sumatra. Economic growth and investment have a significant influence on employment in South Sumatra. The minimum wages in the agricultural and non-agricultural sectors have significant influence on employment in South Sumatra. Some suggestions can be given to provide input on employment policies in the province of South Sumatra. The government should pay attention to establish wage policies for both provincial minimum wages and sectoral wages to increase labor productivity and production growth, in order to absorb more labor. Also, the government should encourage an increase in economic growth in each economy sector so that labor absorption and investment in labor-intensive sectors can be improved. Moreover, the government should be more selective in granting licenses to capital owners which result in higher labor absorption.

\section{References:}

1. Agrawal, N. (1996). The Benefits of Growth for Indonesian Workers. Policy Research Working Paper, World Bank, Vol. 6.

2. Arsyad, L. (1992). Ekonomi Pembangunan. Bagian Penerbitan STIE YKPN. Yogyakarta.

3. Badan Pusat Statistik. Buku Keadaan Angkatan Kerja di Provinsi Sumatera Selatan (2017). Palembang: Badan Pusat Statistik.

4. Badan Pusat Statistik. Buku Sumatera Selatan dalam Angka (2017). Palembang: Badan Pusat Statistik.

5. Bellante, D., Mark, J. (1983). Labor Economic: Choice in Labor Market. New York: McGraw-Hill Book Company.

6. Bienvenido, O. (2010). Temporary Contracts And Labour Productivity In Spain: A Sectoral Analysis. Journal of Productivity Analysis, 34 (2010), 199 -212. https://doi.org/10.1007/s11123-010-0185-z.

7. Boltho, A. \& Andrew, G. (1995). Can Macroeconomic Policies Raise Employment? International Labour Review, 134, $451-470$.

8. Borjas, G. J. (2015). Labor Economics. Seventh Edition. McGraw-Hill-Irwin. International Edition.

9. Choi, K. (2007). The Employment Effect of Economic Growth: Identifying Determinant of Employment Elasticity, Paper, Chonbuk National Univ. 2007, 10. https://doi.org/10.1057/9780230627383_4.

10. Chusna, A. (2013). Pengaruh Laju Pertumbuhan Sektor Industri Terhadap Penyerapan Tenaga Kerja di Provinsi Jawa Tengah. Economics Development Ananlysis Journal, 2 (3), 14-23.

11. Danziger, L. (2009). The Elasticity of Labour Demand and the Minimum Wage. Journal of Population Economics, $22(3), 757-722$. https://doi.org/10.1007/s00148-007-0179-y.

12. Dumairy (1996). Perekonomian Indonesia. Erlangga, Jakarta.

13. Feriyanto, N. \& Sriyana, J. (2016). Labor Absorption Under Minimum Wage Policy In Indonesia. Jurnal Ilmiah. Department of Economics Universitas Islam Indonesia.

14. Fopuhunda, T., Atiku, Olusegun, S. \& Olanrewaju, L. (2011). Minimum Wage Implementation and Management in a Posr Recession Economy : The Nigerian Experience. European Scienjtific Journal, 8(7), 18-35.

15. Ghozali, I. (2011). Aplikasi Analisis Multivariate dan Ekonometrika, Teori, Konsep dan Aplikasi dengan Eviews 10. Semarang: Badan Penerbit Universitas Diponogoro.

16. Gindling, T. H. \& Terrell, K. (2006). The Effects of Multiple Minimum Wage Throughout the Labour Market: The Case os Costa Rica. Journal of Labour Economics, 14, 485-511. https://doi.org/10.1016/j.labeco.2006.01.004.

17. Irawan \& Suparmoko (2002). Ekonomika Pembangunan. Yogyakarta: BPFFE.Islam, Rizwanul. The Nexus of Economic Growth, Employement and Poverty Reduction: An Emperical Analysis. ILO, Geneva.

18. Javed, K., Siah, M. H., Awam, R. U. \& Sher, F. (2001). Foreign Direct Investment, Economic Growth and Employment: Evidance From Pakistan. Interdisciplinsry Journal of Contemporary Research in Business, 3(9), 925-942.

19. Kapos (2005). The Employment Intensity of Growth: Trends and Macroeconomics Determinant. Employment Strategy Papers: International Labour Office, 143-201.

20. Kuncoro, H. (2002). Upah Sistem Bagi Hasil dan Penyerapan Tenaga Kerja. Jurnal Ekonomi Pembangunan. Kajian Ekonomi Negara Berkembang, 7(1), 45- 56.

21. Magruder, J. R. (2013). Can Minimum Wages cause a Big Push? Envidence from Indonesia. Journal of Devolopment Economic, 100-48-62. https://doi.org/10.1016/j.jdeveco.2012.07.003 
Електронне наукове фахове видання з економічних наук «Modern Economics», №18 (2019), 6-14 https://modecon.mnau.edu.ua | ISSN 2521-6392

22. Muhyiddin, T. N. (2018). Ekonomi Ketenagakerjaan. Palembang: Universitas Sriwijaya.

23. Muhyiddin, T. N., Tarmizi, M., Irfan. \& Yulianita, A. (2017). Metodologi Penelitian Ekonomi \& Sosial Teori, Konsep, dan Rencana Proposal. Jakarta: Salemba Empat.

24. Mulyadi, S. (2002). Ekonomi Sumber Daya Manusia. Jakarta: PT Raja Grafindo Persada.

25. Mankiw, N. G. (2006). Makroekonomi. Edisi 6. Terjemahan. Jakarta : Erlangga.

26. Miar (2014). Influence of Economic Growth to Manpower Absorption and People Welfare in Regencies/Cities. Jounal of Economics and Sustainable Development, 5(21).

27. Noviyani (2007). Hubungan Penerimaan dengan Produk Domestik Regional Bruto Perkapita Provinsi di Indonesia. Jurnal Kajian Ekonomi, 1(3), 530-539.

28. Pardi, S. (2007). Faktor-Faktor yang Mempengaruhi Penyerapan Tenaga Kerja. Jurnal Ilmu Ekonomi, 1(10).

29. Setiawan, \& Kusrini, D. E. (2010). Ekonometrika. Yogyakarta : Andi.

30. Sidik, F. (2012). Analisis Kebijakan Upah Minimun terhadap Penyerapan Tenaga Kerja Sektoral di Pulau Jawa, Institut Pertanian Bogor.

31. Simanjuntak, P. J. (1985). Pengantar Ekonomi Sumber Daya Manusia. Penerbit FEUI (Fakultas Ekonomi Universitas Indonesia). Jakarta.

32. SMERU (2001). Dampak Kebijakan Upah Minimum terhadap Tingkat Upah dan Penyerapan Tenaga Kerja di Daerah Perkotaan Indonesia. Retrieved from www.smeru.or.id.

33. Sodik, J. (2005). Investasi dan Pertumbuhan Ekonomi Regional. Jurnal Ekonomi Pembangunan, 10 (2), 157-170.

34. Soeherman, D. A. (2014). The Influential Investment on Economic Growth and Labor Absorption and Public Welfare of District/City in East Java Province. GSTF Journal on Business Review (GBR), 3(4), 45-62.

35. Sulistiawati, R. (2012). Pengaruh Upah Minimum terhadap Penyerapan Tenaga Kerja dan Kesejahteraan Masyarakat di Provinsi di Indonesia. Jurnal Eksos, 8(3), 195 -211.

36. Wahyu, W. W. (2015). Analisis Ekonometrika dan Statistika dengan Eviews (Edisi 4). Penerbit: UPP STIM YKPN. Jakarta.

37. Waisgrais, Sebastian (2003). Wage Inequality and the Labor Market in Argentina: Labor Institutions, Supplyand Demand in the Period 1980-1999. International Institute For Labor Studies Discussion Paper.DP/146/2003 pp 1-53, Decent Work Research Programme. http://doi.org/10.2139/ssrn.334920.

38. Wihastuti, L. (2017). Upah Minimum Provinsi (UMP) dan Penyerapan Tenaga Kerja di Pulau Jawa. Jurnal Gama Societa, 1(1). 